\title{
Stability and Genotype by Environment Interaction Analysis Based on AMMI Model for Seed Yield and Oil Content of Advanced Linseed Breeding Lines
}

\author{
Birhanu Mengistu Aboye* \\ Holetta Agricultural Research Center, P.o. box 31, Holetta, Ethiopia
}

*Corresponding Authors: Birhanu Mengistu Aboye, Holetta Agricultural Research Center, P.o. box 31, Holetta, Ethiopia

\begin{abstract}
The effect of genotype, environment and genotype by environment interaction on seed yield and oil content of 8 linseed genotypes was estimated based on AMMI Model. Analysis of AMMI variance for seed yield and oil content showed highly significant effects $(P \leq 0.001)$ between genotypes, environments and genotype by environment interaction. Environmental effect accounted $63 \%$ and $75.43 \%$ of the total variation for seed yield and oil content respectively. The AMMI-I bi-plot analysis of seed yield, identified G2 and G7 the highest yielder but $G 1$ is better stable and contributed little to genotype by environment interaction. Among the test environments S18, K19 and AD18 are the most discriminating locations. Oil content AMMI-I bi-plot analysis revealed genotypes G7, G4 and G6 were stable and less contribution to genotype by environment interaction and environment K19, B19 and AS9 identified as the most discriminating environments. The stability analysis based on AMMI stability indices for seed yield indicated G1 as stable and high yielder genotype; whereas for oil content G3 and G4 identified as stable genotypes. Generally based on the AMMI-I bi-plot and stability analysis G1, G3 and G4 genotypes are recommended as best genotypes for both seed yield and oil content.
\end{abstract}

Keywords: AMMI, Genotype X Environment, Linseed, Oil content, Seed yield, Stability

\section{INTRODUCTION}

Linseed (Linum usitatissimum L.) belongs to the genus Linum is one of the earliest crop cultivated for its seeds and fiber. Almost every part of the linseed plant is utilized commercially either directly or after processing. It has been under cultivation for its seed oil (linseed) or stem fibers (flax) or both (dual purpose) for 1000 years. The center of origin of cultivated flax is believed to be the Middle East, although secondary diversity centers were identified in the Mediterranean basin, Ethiopia, Central Asia, and India (Zohary and Hopf, 2000).

Nowadays, with the increased consciousness of consumers towards the strong relationship between food and health, linseed started to be considered a very promising functional food, due to the presence, in its seeds, of high amount of nutrients and biologically active compounds, such as fatty acids specifically $\boldsymbol{\alpha}$-linolenic acid (ALA), phytoestrogenic lignans (secoisolariciresinol diglycoside (SDG)), high quality proteins, dietary fibers and phenolic compounds (Xueming, 2010). Among these, ALA is one of the essential polyunsaturated fatty acids (PUFAs) representing the main functional component of linseed. It is clearly demonstrated that linseed represents the best $\square-3$ fatty acid source in vegetarian diets, having also the possibility to be used as additive in the preparation of many dietary products (Reta and Nigussie, 2017).

Ethiopia is the 5th major producer of linseed in the world after Canada, China, United States and India. It is the second most important oil crop in the highlands of Ethiopia in terms of area coverage and production (CSA, 2018). The crop performs best in altitudes ranging from 2200 to 2800 meters above sea level. Traditionally the seed is commonly roasted, ground and mixed with spices and some water to be served along with local breads. It also consumed in soups, soft drinks and with porridges or cooked potatoes. Its industrial use is higher than all other oil crops. It has traditionally been used for food and as a cash crop since ancient times.

The performance of any character is a combined result of the genotype $(G)$ of the variety, the environment (E) and the interaction between genotype and environment (GE). To evaluate the 
consistency of linseed seed yield and develop genotypes that respond optimally and consistently across years and geographic regions, it is necessary to research on yield stability and GE interactions. GE interactions exist when the responses of two genotypes to different levels of environmental stress are not consistent. GE interaction was quantified using several procedures based on evaluation of genotypes under multiple environments. These methods divided into univariate and multivariate stability statistics. Additive main effects and multiplicative interaction (AMMI) model is a popular and an alternative multivariate approach to the joint regression analysis in many breeding programs to study GE interaction (Annicchiarico 1997). This method extracts genotype and environment main effects and uses interaction principal components (IPCs) to explain patterns in the GE interaction or residual matrix, which provides a multiplicative model (Romagosa and Fox, 1993).

The AMMI model combines ANOVA for main effects of the genotype and environment with principal components analysis of GE interactions. Several AMMI parameters were introduced for studying the stability of genotypes across multi environments. AMMI stability value (ASV) (Purchase et al., 2000) is a reliable statistics for GE interaction description and simultaneous selection of yield and stability.

To achieve better economic benefits, identification of linseed varieties with wider adaptability and stability is important for variety recommendation from promising lines. The main objectives of the present study were to identify more high-yielding stable promising linseed lines and determine the areas where linseed genotypes would be adapted using AMMI model.

\section{Materials AND Methods}

\subsection{Planting Materials and Testing Locations}

Eight linseed genotypes developed by hybridization program were grown for two years (2018 and 2019) during the main cropping season (June-November) in six locations representing different linseed growing agro-ecological zones of Ethiopia. Each year and location was treated as a separate environment, making 12 test environments. Descriptions of the six test locations and the 8 test genotypes are presented in Tables 1 .

\subsection{Experimental Design and Layout}

The experiments were laid out in Randomized Completely Block Design (RCBD) with four replications. The gross plot size was $3.6 \mathrm{~m}^{2}$ (six rows spaced at $20 \mathrm{~cm}$ and $3 \mathrm{~m}$ long). A seed rate of $25 \mathrm{~kg} / \mathrm{ha}$ and fertilizer rate $23 / 23 \mathrm{~N} / \mathrm{P}_{2} \mathrm{O}_{5}$ was applied to each plot at planting. Agronomic practices were carried out as per the recommendations uniformly to the entire experimental area.

Table1. Description of the tested locations and genotypes used for evaluation of linseed genotypes during the 2018 and 2019 cropping season in Ethiopia.

\begin{tabular}{|c|c|c|c|c|c|}
\hline \multicolumn{3}{|c|}{ Testing Environment } & \multicolumn{3}{|c|}{ Tested Genotypes } \\
\hline No. & $\begin{array}{l}\text { Testing } \\
\text { Environment }\end{array}$ & $\begin{array}{l}\text { Environment } \\
\text { code }\end{array}$ & No. & Pedigree & $\begin{array}{l}\text { Genotype } \\
\text { Code }\end{array}$ \\
\hline 1 & Holetta2018 & H18 & 1 & CDC 1747 X CI 1652/SPS8 & G1 \\
\hline 2 & Holetta 2019 & H19 & 2 & CI 1652 X CDC 1747/SPS2 & $\mathrm{G} 2$ \\
\hline 3 & Kulumsa 2018 & K18 & 3 & Chilalo X R12-N27G/SPS1 & G3 \\
\hline 4 & Kulumsa 2019 & K19 & 4 & $\begin{array}{lcl}\text { CI } 1652 & \text { X } \\
\text { D33C/SPS105 } & & \\
\end{array}$ & G4 \\
\hline 5 & Adet 2018 & AD18 & 5 & CI 1652 X R12-N27G/SPS5 & G5 \\
\hline 6 & Adet 2019 & AD19 & 6 & R12-100 X CI 1525/SPS1 & G6 \\
\hline 7 & Asasa 2018 & AS18 & 7 & Bekoji-14- SD & G7 \\
\hline 8 & Asasa 2019 & AS19 & 8 & LC-Check & G8 \\
\hline 9 & Bekoji 2018 & B18 & & & \\
\hline 10 & Bekoji 2019 & B19 & & & \\
\hline 11 & Sinana 2018 & S18 & & & \\
\hline
\end{tabular}




\subsection{Statistical Data Analyses}

\section{AMMI Analysis}

To evaluate the interaction effects, the data were subjected to stability analysis following the AMMI model. The AMMI model is a hybrid statistical model incorporating both ANOVA (for additive component) and PCA (for multiplicative component) for analyzing two way (genotype $\mathrm{x}$ environment interaction) data structures based on the following mathematical Model:

$$
\mathrm{Yij}^{\mathrm{v}}=\mu+\mathrm{gi}+\mathrm{ej}+\Sigma \lambda . \mathbf{k} Y \mathbf{i k} \alpha \mathbf{j k}+\Sigma \mathrm{ij}
$$

Where;

$$
\text { Yij = yield of } \mathrm{i}^{\text {in }} \text { genotype in the } \mathrm{j}^{\mathrm{e}} \text { environment. }
$$

$$
\begin{aligned}
& \mu=\text { grand mean } \\
& \text { giej = genotype and environment deviations from the grand mean } \\
& \lambda \mathrm{k}=\text { eigen value of the principal component analysis (PCA) axis } \mathrm{k} \\
& \text { Yik and } \alpha \mathrm{jk}=\text { genotype and environment principal components scores for axis } \mathrm{k} \\
& \mathrm{N}=\text { is the number of principal components in the AMMI model, and } \mathrm{\Sigma ij}=\text { residual term. }
\end{aligned}
$$

\section{AMMI Biplot Analysis}

To show a clear insight into specific GEI combination and the general pattern of adaptation, a biplot of genotypes and environments were done. The AMMI biplot is developed by placing both genotype and environment values on the abscissa (X-axis) and the respective PCA axis, Eigen vector on the Yaxis.

The biplot was also used to explore the interrelationships among environments by constructing lines (environment vectors) from the biplot origin to markers for the environments. The cosine of the angle between environments corresponds to the degree of correlation between environments. The length of the vectors was used to determine the discriminating ability of each of the test environments, with a shorter vector implying that the environment was not well represented by PC1 and PC2 (Yan and Tinker, 2005).

To visualize the performance of the genotypes in each environment and groups of environments, a polygon view was drawn by connecting genotypes that were furthest from the biplot origin such that all genotypes were enclosed within the polygon (Yan, 2002).

\section{AMMI Stability Analysis}

The eigenvalue (EV) stability parameter of AMMI (Zobel et al, 1998) was calculated according to the expression:

$$
E V=\sum_{n=1}^{N} \gamma_{i n}^{2} / n
$$

In this formula, $\gamma^{2} \square$ is the genotype eigenvector for axis $n$, and $N$ is the number of IPCs that were retained in the AMMI procedure via different $F$-test.

The sum of IPCs scores (SIPC) parameter is expressed as (Sneller et al, 1997):

$$
S I P C=\sum_{n=1}^{N} \lambda_{n}^{0.5} \gamma_{i n}
$$

Where, $\lambda$ is the eigenvalue of the IPC analysis axis $n$. In this equation, $\mathrm{N}=1$ for SIPC1; and for $S I P C F, N$ was the number of IPC that were retained in the AMMI model. 
Stability and Genotype by Environment Interaction Analysis Based on AMMI Model for Seed Yield and Oil Content of Advanced Linseed Breeding Lines

ASV was calculated as described by Purchase et al (2000) as follows:

$$
A S V=\sqrt{\left[\frac{\operatorname{SSIPC1}}{\operatorname{SSIPC} 2}(I P C 1)^{2}\right]+(I P C 2)^{2}}
$$

Where: SSIPC1/SSIPC2 is the weight given to the IPC1 value by dividing the IPC1 sum of square by the IPC2 sum of square. The larger IPC score, either negative or positive, the more specifically adapted a genotype is to certain environments. Smaller ASV scores indicate a more stable genotype across environments.

\section{RESULT AND DISCUSSION}

\subsection{AMMI Analysis for Seed Yield and Oil Content}

The result from the AMMI analysis of variance for seed yield and oil content revealed that the difference between genotypes, environments and genotype by environment interaction were highly significant effects $(\mathrm{P} \leq 0.001)$ for genotypes $(\mathrm{G})$, environments(E) and genotype by environment interaction(GEI) (Table 2).

The results revealed that for seed yield $63 \%$ of the total variation was attributable to environmental effects, $16.1 \%$ genotype effects and 20.9 to GE interaction effects. For oil content $75.43 \%$ of the total variation was attributed to environmental effects, 5.31 and $19.26 \%$ attributed to genotype effects and GE interaction effects respectively. Such a large sum and highly significant mean squares of environment indicated that the environments were diverse with large difference amount environmental means causing most of the variation on seed yield and oil content. This shows the overpowering influence that environments can have on the yield and oil performance of linseed. Similar results on the effect of environment and GEI were reported by Cherinet and Tadesse (2014); Jacobs et al., (2015); Tadesse, (2017) and Adane and Abebe, (2018) on linseed genotypes. The significant effects of GE interaction reflected on the differential response of genotypes in various environments demonstrated that it had remarkable effect on genotypic performance in different environments. Therefore, it was possible to proceed and calculate stability parameters. The application of AMMI model for partitioning the GE interaction effect showed that the first two terms of AMMI were significant based on Gollob's F-test (Gollob, 1968) for both seed yield and oil content. In this study, the proportion of IPC1 (59.7\% for seed yield and $65.89 \%$ for oil content) to the interaction sum of squares was far greater than that of IPC2 (Table 2).

Table2. AMMI model ANOVA for Seed yield and oil content of 8 linseed genotypes over 12 tested environments.

\begin{tabular}{|c|c|c|c|c|c|c|c|c|}
\hline \multicolumn{5}{|l|}{ Seed yield } & \multicolumn{4}{|c|}{ Oil Content (\%) } \\
\hline $\begin{array}{ll}\text { Source } \\
\text { variation }\end{array}$ & df & SS & MS & $\begin{array}{l}\text { Variance } \\
\text { explaine } \\
\text { d }(\%)\end{array}$ & df & SS & MS & $\begin{array}{l}\text { Variance } \\
\text { explaine } \\
\text { d (\%) }\end{array}$ \\
\hline Total & $\begin{array}{l}38 \\
3 \\
\end{array}$ & $\begin{array}{l}10445373 \\
7\end{array}$ & $272725 * * *$ & & $\begin{array}{l}25 \\
5\end{array}$ & $\begin{array}{l}1806 . \\
3\end{array}$ & $7.08 * * *$ & \\
\hline Treatments & 95 & 68406771 & $720071 * * *$ & & 63 & $\begin{array}{l}1806 . \\
3\end{array}$ & $28.67 * * *$ & \\
\hline Genotypes & 7 & 10981800 & $\begin{array}{l}1568829 * * \\
*\end{array}$ & 16.1 & 7 & 95.5 & $13.64 * * *$ & 5.31 \\
\hline $\begin{array}{l}\text { Environment } \\
\text { s }\end{array}$ & 11 & 43129152 & $\begin{array}{l}3920832 * * \\
*\end{array}$ & 63.0 & 7 & $\begin{array}{l}1364 . \\
6\end{array}$ & $\begin{array}{l}194.95 * * \\
*\end{array}$ & 75.43 \\
\hline Interactions & 77 & 14295820 & $185660 * * *$ & 20.9 & 49 & 346.1 & $7.06 * * *$ & 19.26 \\
\hline Block & 36 & 14813148 & $411476^{* * * *}$ & & 24 & 0.0 & $0.00 * * *$ & \\
\hline IPCA 1 & 17 & 8539943 & $502350 * * *$ & 59.7 & 13 & 229.3 & $17.64 * * *$ & 65.89 \\
\hline IPCA 2 & 15 & 2839373 & 189292* & 19.9 & 11 & 42.2 & $3.83 * * *$ & 12.41 \\
\hline Residuals & 5 & 63139 & 12628 & & 1 & 0.3 & 0.28 & \\
\hline Error & $\begin{array}{l}25 \\
2\end{array}$ & 21233818 & 84261 & & $\begin{array}{l}16 \\
8\end{array}$ & 0.0 & 0.00 & \\
\hline
\end{tabular}


$*$, **, *** Significant at $0.05,0.01$, and 0.001 probability levels, df degree of freedom, SS sum of square and MS mean square

\subsection{Biplot Analysis}

The GEI was further explored through the genotype and (genotype $\mathrm{x}$ environment) bi-plot analysis. The first two principal components (PCs) of the bi-plot accounted for a total of 79.6\% (IPC1 $=59.74$ $7 \%$, IPC2 $=19.86 \%$ ) of the variation for seed yield over 12 tested environments, while for oil content the PCs explained a total of $78.3 \%$ (IPC1 $=65.89 \%$, IPC2 $=12.41 \%)$ ). In the biplot graphs, the quadrants represent: (Q-I \& QII) higher mean, (Q-III \& Q-IV) lower mean, (Q-I \& Q-IV) +ve IPCA1 and (Q-II \& Q-III) -ve IPCA1 scores.

Genotypes that are grouped together had similar adaptation while environments which were grouped together influence genotypes in the same way. The best adapted genotype can plot far from the environments. In AMMI-I bi-plot genotypes or an environment with IPCA-1 score closer to zero, it has small interaction effect and they are stable across the testing environments, whereas the larger scores depict more specific adaptation to environments with IPC1 scores of the same sign. However, if genotypes far from zero, it is highly responsive and does not perform consistently across the environments (Samonte et al., 2005). But genotypes with high mean performance and large IPCA-1 scores were considered as having specific adaptability to the environments. When a genotype and environment have the similar sign on IPCA-1 axis, their interaction is positive and this genotype is well adapted to this environment. But if they have opposite sign of IPCA-1 scores, their interaction is negative and the environment is not suitable to this genotype (Cross et al., 1990).

Based on the AMMI-I bi-plot analysis of seed yield, Gl and G8 have closer to zero IPCA-1 value therefore, they are better stable and contributed little to the GX E interaction. In addition environments k18 and AS18 contributing little to the G X E interaction (Fig 2a). Oil content analysis revealed genotypes G7, G4 and G6 were stable and less contribution to G X E interaction and environment B18 and AS18 had little contribution to G X E interaction (Fig 2b). When a genotype and environment have the same sign on the PCA axis, their interaction is positive and if different, their interaction is negative (Fig $2 \mathrm{a}$ and $2 \mathrm{~b}$ ).

However, G4, G2 and G7 attained values relatively close to 1, either for both or IPCA-1 with above average yield performance in specific locations and had large G X E interactions. Furthermore, S18, K19, AD18 and AD9 are the most discriminating locations of the test environments (Fig 1a). On the other hand, G2, G5 and G1 attained values relatively close to 1, either for both or IPCA-1 with above average yield performance in specific locations and had large G X E interactions. Furthermore, K19, B19 and AS9 are the most discriminating locations of the test environments (Fig 1b). Connecting vertex cultivars markers in all direction form a polygon, such that all genotypes are contained within the polygon and a set of straight lines that radiate from the biplot origin to intersect each of the polygon sides at right angles form sectors of genotypes and environments (Yan, 2011). Based on AMMI2, a biplot with five sections are formed depending upon signs of the genotypic and environmental IPC scores.

(1a)

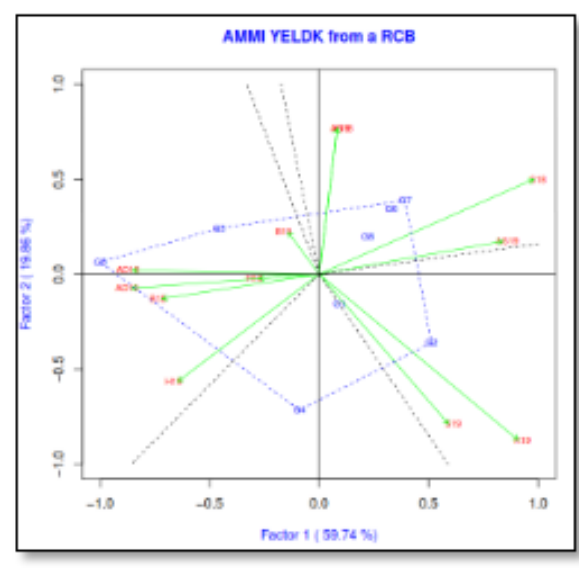

(lb)

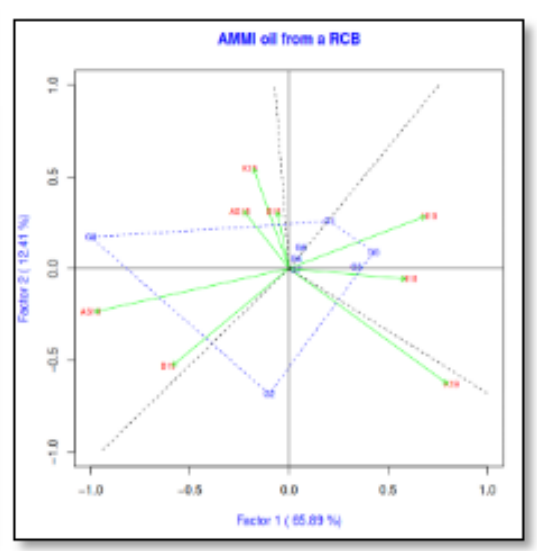

Figure 1 AMMI biplot analysis of the first (IPC1) and second (IPC2) interaction principal component (la) for seed yield and (lb) for oil content 
(2a)

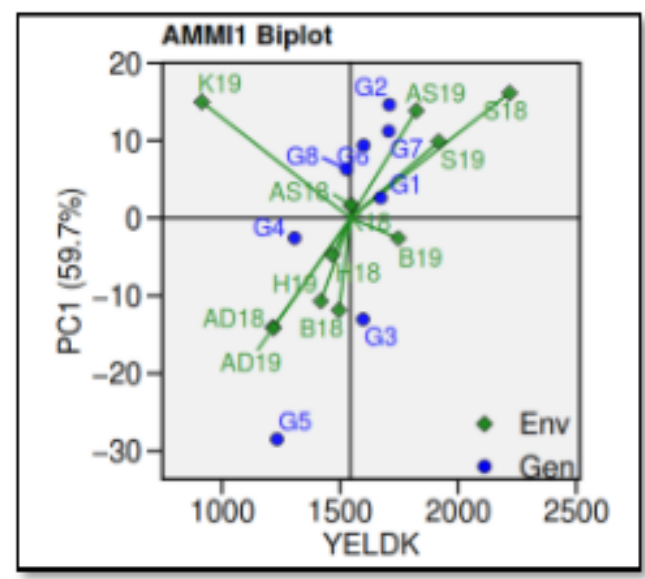

(2b)

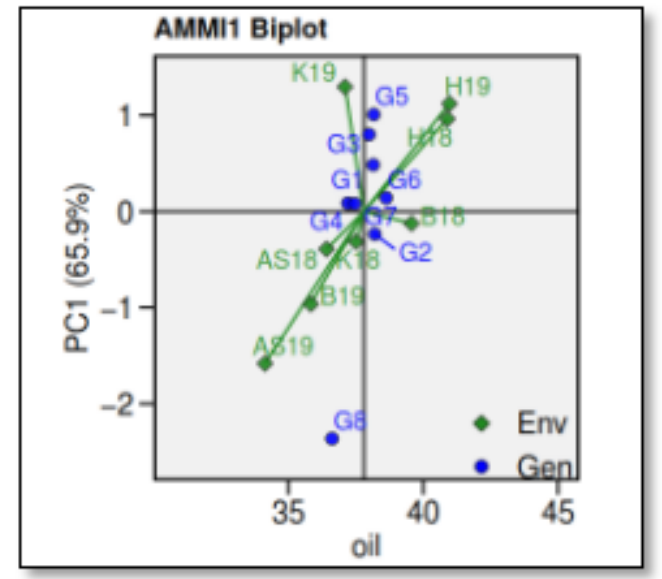

Figure 2 AMMI biplot Analysis of first interaction principal component axis (IPCAl) versus mean seed yields (kg/ha) (2a) and oil content ( $2 \mathrm{~b})$.

\subsection{AMMI Stability Analysis}

The AMMI model does not make provision for a quantitative stability measure, such a measure is essential in order to quantify and rank genotypes according to their yield stability. Therefore AMMI stability parameters are presented in (Table 3). According to the ASV stability statistic, a genotype with lower score value is considered to be more stable; therefore G1, G4 and G8 are stable but G2, G3 and G5 genotypes are unstable for seed yield. Based on ASV stability index for oil content G4, G6 and G7 are stable but G3, G5 and G8 are unstable genotypes. ASV is the distance from zero in a two dimensional scatter gram of IPCA1 (interaction principal component analysis axis 1) scores against IPCA2 scores. Since the IPCA1 score contributes more to GE sum of square.

According to SIPC G1, G6 \& G8 were the most stable genotypes, whereas the most unstable genotypes were G2 \& G5 for seed yield, whereas, G2, G3 \& G4 were stable but G5 \& G8 were unstable for oil content. According to EV value the most stable genotypes for seed yield were G1, G3 \& G8 whereas, G4 \& G5 are unstable genotypes. The EV score for oil content revealed that G2, G3 \& G7 were the most stable but G1 and G6 are unstable genotypes.

Table3. Values of AMMI stability parameters for eight linseed genotypes tasted at 12 environments.

\begin{tabular}{|c|c|c|c|c|c|c|c|c|c|c|c|c|}
\hline \multirow[b]{2}{*}{$\begin{array}{l}\text { Geno } \\
\text { type }\end{array}$} & \multicolumn{6}{|c|}{ Seed yield(Kg/ha) } & \multicolumn{6}{|c|}{ Oil content $(\%)$} \\
\hline & $\begin{array}{l}\text { Poole } \\
\text { d } \\
\text { mean }\end{array}$ & ASV & SIPC & EV & CV & $\mathbf{R}$ & $\begin{array}{l}\text { Poo } \\
\text { led } \\
\text { mea } \\
\text { n }\end{array}$ & ASV & $\begin{array}{l}\text { SIP } \\
\text { C }\end{array}$ & EV & CV & $\mathbf{R}$ \\
\hline G1 & $\frac{1671 .}{\underline{7(3)}}$ & $\frac{9.055}{\underline{(1)}}$ & $\frac{7.074}{\underline{(1)}}$ & $\begin{array}{l}0.01 \\
4(1)\end{array}$ & $\begin{array}{l}25.82 \\
5(5)\end{array}$ & $\begin{array}{l}0.94 \\
3(1)\end{array}$ & $\begin{array}{l}38.2 \\
(4)\end{array}$ & $\begin{array}{l}2.641 \\
(5)\end{array}$ & $\begin{array}{l}3.20 \\
0(7)\end{array}$ & $\begin{array}{l}0.12 \\
5(8)\end{array}$ & $\begin{array}{l}8.01 \\
(6)\end{array}$ & $\begin{array}{l}0.90 \\
(5)\end{array}$ \\
\hline G2 & $\frac{1708 .}{\underline{4(1)}}$ & $\begin{array}{l}45.13 \\
4(7)\end{array}$ & $\begin{array}{l}24.90 \\
6(7)\end{array}$ & $\begin{array}{l}0.13 \\
6(6)\end{array}$ & $\begin{array}{l}24.49 \\
5(3)\end{array}$ & $\begin{array}{l}0.75 \\
3(5)\end{array}$ & $\frac{38.2}{(2)}$ & $\begin{array}{l}2.048 \\
\text { (4) }\end{array}$ & $\frac{2.43}{8(3)}$ & $\frac{0.12}{\underline{5(2)}}$ & $\frac{5.30}{\underline{(2)}}$ & $\begin{array}{l}0.79 \\
(7)\end{array}$ \\
\hline G3 & $\begin{array}{l}1597 . \\
6(5)\end{array}$ & $\begin{array}{l}39.82 \\
4(6)\end{array}$ & $\begin{array}{l}19.92 \\
5(4)\end{array}$ & $\begin{array}{l}0.08 \\
6(3)\end{array}$ & $\begin{array}{l}23.62 \\
4(1)\end{array}$ & $\begin{array}{l}0.75 \\
2(6)\end{array}$ & $\begin{array}{l}38.0 \\
(5)\end{array}$ & $\begin{array}{l}4.251 \\
\text { (6) }\end{array}$ & $\frac{2.11}{\underline{3(1)}}$ & $\frac{0.12}{\underline{5(1)}}$ & $\begin{array}{l}8.16 \\
\text { (7) }\end{array}$ & $\underline{0.95}$ \\
\hline G4 & $\begin{array}{l}1306 . \\
9(7)\end{array}$ & $\frac{21.80}{2(3)}$ & $\begin{array}{l}22.95 \\
7(6)\end{array}$ & $\begin{array}{l}0.24 \\
9(7)\end{array}$ & $\begin{array}{l}23.85 \\
3(2)\end{array}$ & $\begin{array}{l}0.72 \\
0(7)\end{array}$ & $\begin{array}{l}37.2 \\
(7)\end{array}$ & $\begin{array}{l}\underline{0.472} \\
\underline{(2)}\end{array}$ & $\frac{2.33}{7(2)}$ & $\begin{array}{l}0.12 \\
5(4)\end{array}$ & $\begin{array}{l}7.31 \\
(5)\end{array}$ & $\frac{0.96}{\underline{(2)}}$ \\
\hline G5 & $\begin{array}{l}1233 . \\
0(8)\end{array}$ & $\begin{array}{l}85.70 \\
0(8)\end{array}$ & $\begin{array}{l}30.28 \\
8(8)\end{array}$ & $\begin{array}{l}0.28 \\
0(8)\end{array}$ & $\begin{array}{l}28.01 \\
6(7)\end{array}$ & $\begin{array}{l}0.27 \\
9(8)\end{array}$ & $\frac{38.2}{\underline{(3)}}$ & $\begin{array}{l}5.358 \\
\text { (7) }\end{array}$ & $\begin{array}{l}3.14 \\
1(6)\end{array}$ & $\begin{array}{l}0.12 \\
5(5)\end{array}$ & $\begin{array}{l}9.25 \\
(8)\end{array}$ & $\begin{array}{l}\underline{0.97} \\
\underline{(1)}\end{array}$ \\
\hline
\end{tabular}


Stability and Genotype by Environment Interaction Analysis Based on AMMI Model for Seed Yield and Oil Content of Advanced Linseed Breeding Lines

\begin{tabular}{|c|c|c|c|c|c|c|c|c|c|c|c|c|}
\hline G6 & $\begin{array}{l}1599 . \\
9(4)\end{array}$ & $\begin{array}{l}29.87 \\
5(4)\end{array}$ & $\frac{19.18}{\underline{7(3)}}$ & $\begin{array}{l}0.08 \\
7(4)\end{array}$ & $\begin{array}{l}29.14 \\
5(8)\end{array}$ & $\begin{array}{l}0.92 \\
5(2)\end{array}$ & $\frac{38.6}{\underline{\text { (1) }}}$ & $\frac{0.799}{\underline{(3)}}$ & $\begin{array}{l}2.60 \\
4(5)\end{array}$ & $\begin{array}{l}0.12 \\
5(7)\end{array}$ & $\frac{7.04}{\underline{(3)}}$ & $\begin{array}{l}0.88 \\
(6)\end{array}$ \\
\hline G7 & $\frac{1705 .}{8(2)}$ & $\begin{array}{l}35.42 \\
8(5)\end{array}$ & $\begin{array}{l}22.26 \\
3(5)\end{array}$ & $\begin{array}{l}0.11 \\
6(5)\end{array}$ & $\begin{array}{l}27.01 \\
0(6)\end{array}$ & $\begin{array}{l}0.86 \\
7(3)\end{array}$ & $\begin{array}{l}37.5 \\
(6)\end{array}$ & $\frac{\mathbf{0 . 4 2 7}}{\underline{(1)}}$ & $\begin{array}{l}2.48 \\
7(4)\end{array}$ & $\frac{0.12}{5(3)}$ & $\begin{array}{l}7.16 \\
\text { (4) }\end{array}$ & $\begin{array}{l}0.94 \\
(4)\end{array}$ \\
\hline G8 & $\begin{array}{l}1527 . \\
4(6)\end{array}$ & $\frac{19.70}{6(2)}$ & $\frac{11.86}{6(2)}$ & $\begin{array}{l}0.03 \\
2(2)\end{array}$ & $\begin{array}{l}25.77 \\
5(4)\end{array}$ & $\begin{array}{l}0.86 \\
6(4)\end{array}$ & $\begin{array}{l}36.6 \\
(8)\end{array}$ & $\begin{array}{l}12.56 \\
0(8)\end{array}$ & $\begin{array}{l}3.28 \\
6(8)\end{array}$ & $\begin{array}{l}0.12 \\
5(6)\end{array}$ & $\frac{5.16}{(1)}$ & $\begin{array}{l}0.14 \\
(8)\end{array}$ \\
\hline
\end{tabular}

ASV = AMMI stability Value; SIPC $=$ sum of IPCs scores; $\quad \mathrm{EV}=$ eigenvalue stability parameter; $\mathrm{CV}=$ Coefficient of variation

When we compare the coefficient of determination (CV) value G1, G8 and G3 considered as stable genotypes but G4 and G5 are unstable for seed yield whereas G2, G6 and G8 are stable and G3 and G5 are unstable genotypes for oil content. As a general rule CV values with lowest score are considered as stable genotypes across locations. The R value presented in table showed G1 and G6 as stable but G4 and G5 unstable genotypes for seed yield but for oil content G3, G6 and G8 are stable whereas $\mathrm{G} 2$ and $\mathrm{G} 8$ are unstable genotypes.

Generally based on the stability analysis for seed yield G1 is selected as stable genotype by most of the parameters; it is also among the top high yielder genotype and G5 is unstable low yielder genotype based on mean seed yield value. For oil content G3 and G4 is stable with SIPC, EV and CV parameters and moderately stable by ASV; this genotype is among the top high yielder and high oil content genotypes. G8 is a low oil value and the least stable genotype by most of the stability parameters.

\section{CONCLUSION}

Genotype-by-environment (GE) interaction has been an important and challenging issue among plant breeders, geneticists and agronomists engaged in performance testing. The genotype-environment interaction reduces association between phenotypic and genotypic values and leads to bias in the estimates of gene effects and combining ability for various characters sensitive to environmental fluctuations. Both high value of trait interest (i.e. yield and oil) and stability of performance should be considered simultaneously to reduce the effect of GE interaction and to make selection of genotypes more precise and refined. The results of this investigation showed there were desirable genotypes in terms of high oil content G3 and G4 and for seed yields G1 in terms of high mean yield and stability. Therefore, these genotypes will be used for further breeding program.

\section{ACKNOWLEDGEMENT}

The author would like to acknowledge the financial support from EIAR. Collaborative research centers Kulumsa, Sinana and Adet and all research staff of the Holetta National High and Midland Oilseeds research program for their immense contributions for the accomplishment of the experiment.

\section{REFERENCES}

[1] Chobe, A.C. and Ararsa, A.D., 2018. AMMI and GGE Biplot Analysis of Linseed (Linum usitatissimum L) Genotypes in Central and South-Eastern Highlands of Ethiopia. Journal of Plant Breeding and Genetics, 6(3), pp.117-127.

[2] Cherinet, A. and Tadesse, D., 2014. Study on Genotype x Environment interaction of seed yield, oil content, fatty acid profile and stability analysis of yield related trait in Linseed (Linum usitatissimum L.) in North Western Ethiopia. Int. J. Pl. Breed. Gen, 8, pp.66-73.

[3] Crossa, J., Gauch Jr, H.G. and Zobel, R.W., 1990. Additive main effects and multiplicative interaction analysis of two international maize cultivar trials. Crop Science, 30(3), pp.493-500.

[4] CSA, 2018. The Federal Democratic Republic of Ethiopia Central Statistical Agency report on area and production of major crops. Addis Ababa,Ethiopia.

[5] Gollob, H.F., 1968. A statistical model which combines features of factor analytic and analysis of variance techniques. Psychometrika, 33(1), pp.73-115.

[6] Jacobsz, M. J., W. J. C. V. Merwe and M. M. V. Westhuizen. 2015. Additive Main Effects and Multiplicative Interaction Analysis of European Linseed (Linum Ustatissimum L.) Cultivars under South African Conditions. Advances in Plants \& Agriculture Research, 2: 120-124. 
[7] Purchase J L, Hatting H, van Deventer C S. 2000. Genotype $\times$ environment interaction of winter wheat (Triticum aestivum L.) in South Africa: II. Stability analysis of yield performance. South Afric J Plant Soil, 17: 101-107.

[8] Reta D, Nigussie D (2017). Effect of Nitrogen and Sulphur on Nitrogen and Sulphur Uptake in Linseed (Linumusitatissimum L.) in Sinana, Southeastern Ethiopia. International Journal of Applied Agricultural Sciences 3(5):111-116

[9] Romagosa, I., Fox, P.N., Del Moral, L.G., Ramos, J.M., Del Moral, B.G., De Togores, F.R. and MolinaCano, J.L., 1993. Integration of statistical and physiological analyses of adaptation of near-isogenic barley lines. Theoretical and Applied Genetics, 86(7), pp.822-826.

[10] Samonte, S.O.P., Wilson, L.T., McClung, A.M. and Medley, J.C., 2005. Targeting cultivars onto rice growing environments using AMMI and SREG GGE biplot analyses. Crop science, 45(6), pp.2414-2424.

[11] Sneller, M.C., Wang, J., Dale, J.K., Strober, W., Middelton, L.A., Choi, Y., Fleisher, T.A., Lim, M.S., Jaffe, E.S., Puck, J.M. and Lenardo, M.J., 1997. Clinical, immunologic, and genetic features of an autoimmune lymphoproliferative syndrome associated with abnormal lymphocyte apoptosis. Blood, The Journal of the American Society of Hematology, 89(4), pp.1341-1348.

[12] Tadesse, T. 2017. AMMI Model for Yield Stability Analysis of Linseed Genotypes for the Highlands of Bale, Ethiopia. Plant, 5: 93-98.

[13] Toure, A.; Xueming, X. 2010. Flaxseed lignans: Source, biosynthesis, metabolism, antioxidant activity, bio-active components and health benefits. Compr. Rev. Food Sci. Food Saf. 9, 261-269.

[14] Yan, W. and Tinker, N.A., 2005. An integrated biplot analysis system for displaying, interpreting, and exploring genotypex environment interaction. Crop Science, 45(3), pp.1004-1016.

[15] Yan, W., 2002. Singular-value partitioning in biplot analysis of multienvironment trial data. Agronomy Journal, 94(5), pp.990-996.

[16] Yan, W., 2011. GGE biplot vs. AMMI graphs for genotype-by-environment data analysis. Journal of the Indian Society of Agricultural Statistics, 65(2), pp.181-193.

[17] Zobel, R. W., M. J. Wright and H. G. Gauch. 1988. Statistical Analysis of a Yield Trial. Agronomy Journal, 80: 388-393.

[18] Zohary, D., Hopf, M., 2000. Domestication of Plants in the Old World: The Origin and Spread of cultivated Plants in West Asia, Europe and the Nile Valley. Oxford University Press, Oxford, p. 316.

Citation: Birhanu Mengistu Aboye, " Stability and Genotype by Environment Interaction Analysis Based on AMMI Model for Seed Yield and Oil Content of Advanced Linseed Breeding Lines” International Journal of Research Studies in Agricultural Sciences (IJRSAS), 2021; 7(2), pp. 23-30, https://doi.org/10.20431/24546224.0702004

Copyright: (C) 2021 Authors. This is an open-access article distributed under the terms of the Creative Commons Attribution License, which permits unrestricted use, distribution, and reproduction in any medium, provided the original author and source are credited. 